\title{
Inter-Sectorial Linkage of Economic Sectors and aße Their Contribution to Economic Growth: A ResearchHouse Time Series Evidence from Ethiopia and China
}

\author{
Abrham Tezera Gessesse ${ }^{1^{*}}$, Zheng Xungang ${ }^{2}, \mathrm{He} \mathrm{Ge}^{3}$ \\ ${ }^{1} \mathrm{PhD}$ Candidate, Collage of Management, Sichuan Agricultural University, Chengdu, CHINA \\ ${ }^{2,3}$ Collage of Economics, Sichuan Agricultural University, Chengdu, CHINA \\ *E-mail for correspondence: abrhamtezera@gmail.com
}

Received: Sep 02, 2017

Accepted: Jan 27, 2018

Published: Mar 18, 2018

Source of Support: Nil

No Conflict of Interest: Declared

\begin{abstract}
Purpose: The aim of this paper is to investigate the inter-sectorial linkage of economic sectors and their contribution to the economic growth using time series data from 1978-2014 and 1992-2014.

Design/methodology/approach: This study employed a Johansen cointegration test and Ordinary Least Square (OLS) model.

Findings: The Johansen cointegration and multiple regression results indicate that all economic sectors have strong, positive and significant long-run and short-run relationship with economic growth during the study period in both countries. The result revealed that MNF giant is an engine for Chinese economic growth while agriculture took the lion-share for Ethiopian economy. The MNF has bi-directional Granger cause with economic growth, agriculture and SRV for China, while GDP and AGR are the only bi-directional Granger causes variables for Ethiopia.

Implications: Therefore, from a policy perspective, Ethiopian policymakers need to formulate agro-processing industries to ensure the transformation of the AGR to the MNF as well as maintain inter-sectorial linkage and sustain the country's economic growth.
\end{abstract}

Keywords: Economic sectors, Economic growth, Granger cause, Ethiopia, China

\section{INTRODUCTION}

The Chinese and Ethiopian economic growth were poor before their economic reforms and mainly concerned with subsistence agriculture. Since the beginning of economic reforms in 1978 and 1992 in China and Ethiopia, respectively, spectacular fast economic growth has been overlooked and escape hundreds of thousands of people from poverty in both countries. The economic reform of both country characterized by trade liberalization which open up to the international market and foreign investment and gave more attentions to manufacturing and industry sector. This creates widespread job opportunities and employment and improves per-capita Gross Domestic Product (GDP). In China, the growth of manufacture and industrial sector much higher compare to Ethiopia as Ethiopia focusing more on its labor market instead of the capital market.

In recent decades policymakers in most developing countries had realized the importance of manufacturing and industrialization sectors. On the other hand, the importance of the agricultural sector to economic growth still play a magnificent role in many countries like Ethiopia. However, economic analysis largely has neglected interdependence and linkages among economic sectors, concentrating instead on either macroeconomic or single sector and subsector issues. Therefore, understanding the interdependency and linkage of economic sectors such as agriculture, manufacture, and SRV are critical for the overall economic development of countries.

\section{China's Economic Overview}

Before the initiation of economic reforms and trade liberalization, China's economy was long period downturn which is very poor, stagnant, centrally controlled, vastly inefficient, and relatively isolated from the global economy. However, since the introduction and opening up to foreign trade and implementing free market economic reforms in 1978, China has been among the world's fastest-growing economies, which an average real annual gross domestic product (GDP) growth approximately $10 \%$ for last three decades. According to IMF China is the world's second largest economy by nominal GDP, world's largest economy by purchasing power party (PPP) basis, and emerged as a major global economic power.

Agriculture has made a tremendous contributions to the national economic growth and a vital industry which still employed over $34 \%$ of total population and account for 
$10 \%$ of national GDP ( $1 \%$ GDP) while its contribution has been sleeping from year to year. When China's economic reform was minded in 1978, China moving away from the less effective Commune Farming System (CFS) to Household Responsibility System (HRS) and the agricultural production achieved a remarkable result and highly contribute to Chinese economic growth and escape hundred thousand of people from poverty. The system provides opportunities to farmers products to global market, traditional rural markets were reestablished throughout the countryside, and free markets were re-established in urban areas. Thus, China becomes the world's largest agricultural products producer and exporter as well as the consumer. The agricultural sector in China also highly contributed to the growth and development of industrial sector (Lin and Koo, 1990).

The transformation of sleeping rural agricultural giant to manufacturing and SRV kingpin which had brought rapid infrastructure development, urbanization, rising per capita income and a big shift in the composition of its GDP. The emergence of manufacturing powerhouse has been astonishing to become the world's largest producer of industrial goods and also used its huge manufacturing engine to boost living standards by doubling the country's GDP per capita over a decade. Furthermore, the manufacturing sector generates more job opportunities and attracts foreign investment.

Unlocking the enormous potential of the services sector is needed to strengthen the business sector, provide jobs for a rapidly growing labor force, facilitate trade, accelerate the adoption of advanced management methods and increase overall economic efficiency. The development of the services sector in China has been constrained by the country's focus on manufactured exports and the substantial barriers to trade and investment in the services sector for many years. In earlier decades no heed was paid to the SRV; it still accounts for a smaller percentage of GDP compared to the global average for developing countries. However, its sector has gotten the attention of the Chinese government, which constituted in the $12^{\text {th }}$ five-year plan to prioritize the development of service economy along with Trade in Services (TIS). The services sector has grown strongly, but it is still smaller than it should be for an economy at China's stage of economic development (Fig. 1). China's SRV has doubled in size over the last two decades to account for about $46 \%$ of GDP (4.6\% GDP) while still much lower than countries like the U.S. (79\%), Japan (73\%), Brazil (69\%) and India (57\%).

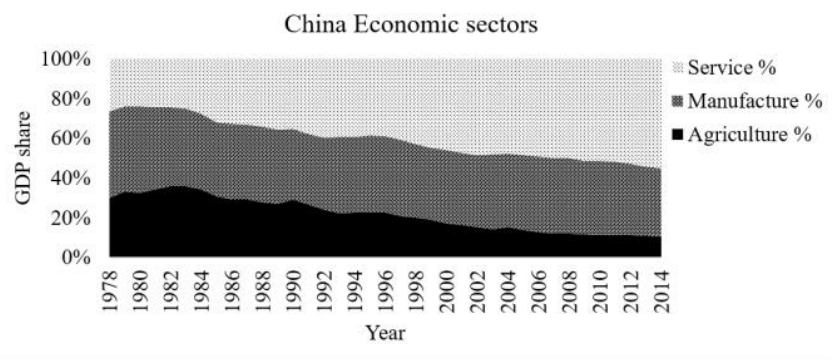

Fig. 1: Chinese economic sectors share to GDP

\section{Ethiopian economic overview}

Ethiopia is a second most populated country in Africa (estimated about 95.9 million) and $79.1 \%$ are economically active in agriculture (ADB, 2015). Pre-1991 under Imperial Monarch and Military Regime (Derg) the country economy extremely poor and most resources of the country owned by the governments. After the current Ethiopian People Democratic Revolution Front (EPDRF) government comes to power in 1991, the market-oriented liberalized economy began. Since then the government had made a broad range of economic reforms, policies and strategies to attain the country to middle-income level countries by 2025 by taking agricultural sector as a lead for the future industrialized economy and witnessed a significant annual economic growth. The Ethiopia economy has experienced strong and broad-based growth over the past decade, averaging $10.8 \%$ per year in 2003/04 to $2013 / 14$ compared to the regional average of $4.8 \%$. Over the past two decades, there has been also significant progress in the key human capital development of the country.

The Ethiopian economy is highly dependent on agricultural production. The agricultural sector generates the lion-share on foreign currency earning and contribute $39.9 \%$ of Gross Domestic Product (GDP) of the country for many decades while its share went down from year to year and improve the manufacturing and service (hotel tourism) sectors (NBE, 2014).

On the other hand, the share of the industrial sector (including manufacture, construction) to GDP is very low despite its faster growing than the agriculture and SRVs recently. This calls for expanding the manufacturing sector taking into account the country's competitive advantage. In 2013/14 the manufacturing sector contributes $30.8 \%$ to industrial output growth (approximately $4.4 \%$ real GDP) while the construction industry contributes more than half $(53.1 \%)$ to the industrial sector and $7.4 \%$ GDP growth (NBE, 2014).

The SRV becoming the dominant economic sector since 2010 by overtook the agricultural sector and share approximately $46 \%$ of the GDP which accounts more than half $(51.7 \%)$ to GDP by $2013 / 2014$. This significant contribution to GDP had become gripping by massive subsector growth such as Whole Sale and Retail Trade service, Real Estate, Hotel and Tourism, Transport and communication etc.

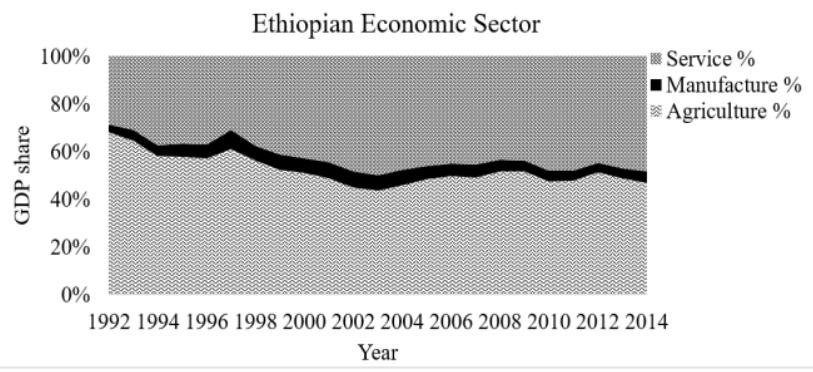

Fig. 2: Ethiopian economic sectors share to GDP 
Since the reform began in these countries in the late 1970s and early 1990s, the agricultural and food systems of these transition economies went through major restructuring processes such as market liberalization, farm restructuring, reform of upstream and downstream operations, and the creation of supporting market infrastructure. These restructuring processes induced major changes in the commodity mix and volume of agricultural production, consumption, and trade, and likely a more complex system of inter-sectorial relationships since the manufacture and SRV were allowed to play a greater role in the economy in China and Ethiopia in recent years.

\section{Empirical evidence}

A number of development economists attempted to evaluate the contributions of economic sectors to the economic growth as well as their linkage were employed such as Mirza and Uddin (2015) for Bangladesh; Chang, Chen and Hsu, (2006) for Japan, Taiwan and Korea; Subramaniam and Reed, (2009) for Romania and Poland; Katircioglu (2006) for North Cyprus; Linden and Mahmood (2007) for Schengen Countries; Libanio (2006) for Latin American countries; Elhiraika, (2008) for African countries and Blunch and Verner (2006) Zimbabwe. These empirical studies have made useful contributions to understanding the links between different economic sectors in the economic growth of the country. In China, many empirical studies were also conducted on the relationship between economic sectors and their contribution to the country economic growth as a single country and cross-country basis (Wang and Li 2010; Hussin and Yik, 2012; Hussin and Ching, 2013; Wang, et al. 2010) while there is a lack of research evidence about Ethiopian. Therefore, this study attempted to identify the pattern of changes in economic sectors composition that characterizes the economic dynamics of two transition countries (China and Ethiopia) by applying a multisectorial endogenous growth framework. The study will be significant since China and Ethiopia are under faster economic growth. This study may assist policymakers to identify the optimal policies to continue further economic growth in these countries. The objectives of this study are: to investigate the interdependency and linkage of agriculture, manufacture and services sectors and their contribution to economic growth; to investigate the existence of long-run and short-run growth relationships economic sectors to economic growth; and finally to determine the Granger causality among economic sectors and with economic growth. This study employs the Johansen procedure of cointegration analysis, Granger causality analysis, and multiple regression analysis to identify the existence long-run and short-run inter-sectorial linkages among different economic giants in the economies and their contribution to the economic development of the countries.

\section{Data ANd Methodology}

\section{Data}

Annual time series data were collected from a World Development Indicator (WDI) which published online at http://databank.worldbank.org/data/reports from 1978 to 2014 and 1992 to 2014 for China and Ethiopia, respectively. The data on the pre-transition period (prior to 1978 and 1992) was not used in this study since the command economic system was not comparable and fundamentally different from a market economic system. All variables are employed with their natural logarithms form to reduce heteroscedasticity.

\section{Definition of the variables}

Gross Demotic Product (GDP): GDP is the sum of gross value added by all resident producers in the economy plus any product taxes and minus any subsidies not included in the value of the products. It is calculated without making deductions for depreciation of fabricated assets or for depletion and degradation of natural resources. GDP at market price is in current USD.

Agriculture (AGR) sector: It is also known as a primary sector in economy Agriculture corresponds to International Standard Industrial Classification (ISIC) divisions 1-5 and includes forestry, hunting, and fishing, as well as cultivation of crops and livestock production. Agriculture value added is in current USD.

Manufacture (MNF) sector: which includes manufacturing, construction, public utilities, and mining. It is also known as a secondary sector in economy Manufacturing refers to industries belonging to ISIC divisions 15-37. Value added is the net output of a sector after adding up all outputs and subtracting intermediate inputs. It is calculated without making deductions for depreciation of fabricated assets or depletion and degradation of natural resources. Manufacture value added is in current USD.

Service (SRV) sector: Services sector is an industry which does not produce raw materials or manufactured products but offers services. It is also known as a tertiary sector in the economy. The services sector primarily consists of wholesale and retail trade including hotels and restaurants; transportation; and government, financial, professional, and personal services such as education, health care, and real estate services. Besides, it also includes imputed bank service charges, import duties, and any statistical discrepancies noted by national compilers as well as discrepancies arising from rescaling. Services value added is in current USD.

\section{Model specification}

Reconsidering recent econometric studies, this study used Cobb-Douglas production function:

$G D P_{t}=f\left(A G R_{t}, M N F_{t}, S R V_{t}\right)$

This essentially states that the total Gross Domestic Product (GDP) value added is a function of agricultural value added (AGR), manufacture value added (MNF) and the service sector value added (SRV). Since our study is a time series, we re-write the equation (1) as linear regression model:

$\ln G D P=\beta_{0}+\beta_{1} \ln A G R+\beta_{2} \ln M N F+\beta_{3} \ln S R V+\varepsilon$

Where, $\beta_{0}$ is intercept, $\beta_{1}, \beta_{2}$, and $\beta_{3}$ are parameters to be estimated and $\varepsilon$ error term.

\section{Unit root test}

Unit root test is used to identify whether all variables are stationary and integrated at the same order or not. Most of the econometric models namely Vector Error Correction Model (VECM), Vector Autoregression Model (VAR) and linear regressions require stationary data for every variable. Thus, before moving further analysis of the variables, it needed to ensure stationary properties of the variables. An Augmented Dickey-Fuller (ADF) test (Dickey and Fuller, 1979; 1981) was used 
to perform unit root tests. Unit root tests are generally employed in order to identify the variables that belong to a stationary series. The null hypothesis of the test is that the variables have a unit root. ADF test includes extra lagged terms of the dependent and independent variables in order to eliminate autocorrelation.

$\Delta Y_{t}=\beta_{0}+\beta_{1} t+\beta_{2} Y_{t-1}+\varepsilon_{t}$

Where $\Delta$ is the first difference, $\mathrm{t}$ is the time index, $\varepsilon$ is error term.

From a methodological perspective, the ADF test maintains three trend assumptions:

- no intercept and no trend,

- intercept with the trend, and

- intercept and without trend.

In this study, we used the $2^{\text {nd }}$ and $3^{\text {rd }}$ assumptions and expressed using equations 4 and 5, respectively.

$\Delta y_{t}=\alpha+\delta y_{t-1}+\sum_{i=1}^{p} \alpha_{i} \Delta y_{t-i}+\varepsilon_{t}$

$\Delta y_{t}=\alpha+\beta_{t}+\delta y_{t-1}+\sum_{i=1}^{p} \alpha_{i} \Delta y_{t-i}+\varepsilon_{t}$

\section{Cointegration test}

Cointegration means that despite being individually nonstationary, a linear combination of two or more time series data can be stationary (Gujarati, 2011). When a linear combination of non-stationary variables are stationary, the variables are said to be cointegrated and the vector that is quite possible for a linear combination of integrated variables to be stationary. With respect to cointegration analysis, Engle and Granger (1987) point out that a linear combination of two or more nonstationary series may be stationary. Since the variables are integrated in the same order, cointegration is used to estimate the long-run relationship between the variables. In this study Johansen's and Juselius (1990) method used to test for cointegration between the series of agriculture, manufacture, SRV, and GDP growth. The cointegration technique uses two tests the maximum Eigenvalue statistics and traces statistics in estimating the number of cointegration vectors.

\section{Granger causality test}

Granger causality tests are widely used to investigate causal relationships between variables. The Granger causality test is a statistical hypothesis test for determining whether one variable affects another. Granger (1969) approached to the question of whether $x$ causes $y$ is to see how much of the current $y$ can be explained by past values of $y$ and then to see whether adding lagged values of $x$ can improve the explanation. $y$ is said to be Granger-caused by $x$ if $x$ helps in the prediction of $y$, or equivalently if the coefficients on the lagged $X^{\prime}$ s are statistically significant. Note that two-way causation is frequently the case; $x$ Granger causes y and y Granger causes $x$.

$$
\begin{aligned}
& y_{t}=\alpha_{0}+\sum_{i=1}^{m} \alpha_{i} y_{t-i}+\sum_{i=1}^{m} \beta_{i} x_{t-i}+\varepsilon_{t} \\
& x_{t}=\alpha_{0}+\sum_{j=1}^{n} \alpha_{i} y_{t-j}+\sum_{j=1}^{n} \beta_{j} x_{t-j}+\varepsilon_{t}
\end{aligned}
$$

The null hypothesis (H0) and the alternative hypothesis (H1) for equation 6 and 7 can be written as:

$\mathrm{H} 0: \beta_{\mathrm{i}}=0, \mathrm{i}=1,2,3 \ldots \mathrm{m}$ and $\beta_{\mathrm{j}}=0, \mathrm{j}=1,2,3 \ldots \mathrm{n}$

H1: $\beta_{i} \neq 0, i=1,2,3 \ldots m$ and $\beta_{j} \neq 0, j=1,2,3 \ldots n$

\section{Model stability checking}

The existence of a cointegration between the constructed variables does not imply that the estimated coefficients are stable. Thus, to ensure the Goodness-of-Fit (GoF) of the model, the diagnostic and stability test of the model also conducted using heteroscedasticity. In addition, in order to check the stability of the long-run coefficients cumulative sum (CUSUM) and cumulative sum square (CUSUMSQ) will employ as indicated in Brown et al. (1975). Graphically, these two statistics are plotted within two straight lines bounded by the $5 \%$ significance level. Plots of these statistics fall inside the critical bounds of $5 \%$ significance, one assumes that the coefficients of the given regression are stable and the null hypothesis will be accepted. But, if any point lies beyond this $5 \%$ level, the null hypothesis of stable parameters will be rejected.

\section{EMPIRICAL RESULT}

\section{Stationary (Unit-Root Test) Analysis}

Prior to conducting the cointegration test to examine the longrun relationship between GDP, AGR, MNF and SRV, it is necessary to test the stationarity of the variables; this is also known as a unit-root test. Under the H0, there is a unit root problem while in the $\mathrm{H} 1$ there is no unit root problem. This study weighted unit root tests using ADF and PP tests. The ADF test result (Table 1) shows that none of the constructed variables are stationary at their level form intercept with the trend and without trend and fail to reject the unit root hypothesis. This indicated that there is a unit root problem on the variables. However, the time series data of the constructed variables at their first differenced they become stationary indicating that no unit root problems. The PP test is also consistent with the ADF test. From the unit root test result, we found the order of integration of all variables to be stationary at either difference. Hence, we can confidently endorse to Johansen cointegration test approaches.

\begin{tabular}{|c|c|c|c|c|c|c|c|c|c|c|c|c|c|c|c|c|}
\hline \multirow[t]{4}{*}{ Variables } & \multicolumn{8}{|c|}{ China } & \multicolumn{8}{|c|}{ Ethiopia } \\
\hline & \multicolumn{4}{|c|}{ Intercept with trend } & \multicolumn{4}{|c|}{ Intercept without trend } & \multicolumn{4}{|c|}{ Intercept with trend } & \multicolumn{4}{|c|}{ Intercept without trend } \\
\hline & \multicolumn{2}{|c|}{ Level } & \multicolumn{2}{|c|}{$1^{\text {st }}$ Differences } & \multicolumn{2}{|c|}{ Level } & \multicolumn{2}{|c|}{$1^{\text {st }}$ Differences } & \multicolumn{2}{|c|}{ Level } & \multicolumn{2}{|c|}{$1^{\text {st }}$ Differences } & \multicolumn{2}{|c|}{ Level } & \multicolumn{2}{|c|}{$1^{\text {st }}$ Differences } \\
\hline & ADF & $\mathrm{PP}$ & ADF & PP & ADF & PP & $\mathrm{ADF}$ & PP & $\mathrm{ADF}$ & PP & $\mathrm{ADF}$ & PP & ADF & PP & ADF & PP \\
\hline GDP & -0.9 & -1.1 & $-4.3^{* * *}$ & $-4.1^{* *}$ & 2.19 & 1.9 & $-3.7^{* * *}$ & $-3.7^{* * *}$ & -1.8 & -2.2 & $-4.3^{* *}$ & -3.1 & 0.39 & 1.6 & $-2.8^{*}$ & $-2.7^{*}$ \\
\hline AGR & -0.7 & -1.0 & $-4.7^{* * *}$ & $-6.2^{* * *}$ & 0.99 & 0.9 & $-4.4^{* * *}$ & $-4.4^{* * *}$ & -2.1 & -2.2 & -2.8 & -3.1 & 0.58 & 0.3 & $-3.0 *$ & $-2.9 *$ \\
\hline MNF & -2.1 & -1.3 & $-4.2^{* *}$ & $-4.2^{* *}$ & 1.39 & 2.2 & $-3.6^{* *}$ & $-3.5^{* *}$ & -1.6 & -1.6 & $-4.9^{* * *}$ & $-4.9^{* * *}$ & 0.54 & 0.8 & $-4.7^{* * *}$ & $-4.7^{* * *}$ \\
\hline SRV & 0.02 & -1.6 & $-6.5^{* * *}$ & $-5.6^{* * *}$ & 3.71 & 3.4 & $-2.9 *$ & $-4.2 * * *$ & -2.3 & -2.3 & $-3.8^{* *}$ & $-3.7^{* *}$ & 2.06 & 2.1 & $-3.2 * *$ & $-3.1 * *$ \\
\hline
\end{tabular}

Table 1: The unit root test results for China and Ethiopia 


\section{Cointegration Analysis}

Since the variables were found to be stationary at the first difference, we were able to proceed with the cointegration test. The cointegration test used in this paper was proposed by Johansen (1988) and Johansen and Juselius (1990). The cointegration results are presented in Table 2 and Table 3 for China and Ethiopia, respectively. As indicated in Table 2, we found that two cointegrating relationships among GDP, AGR, MNF and SRV at the 5\% significance level.

Table 2: Johansen Cointegration test intercept with tend for China

\begin{tabular}{|c|c|c|c|c|c|c|c|}
\hline \multirow[t]{3}{*}{ Hypothesized No. of CE(s) } & \multirow[t]{3}{*}{ Eigenvalue } & \multicolumn{6}{|c|}{ Unrestricted Cointegration Rank Test Intercept with Trend } \\
\hline & & \multicolumn{3}{|c|}{ Trace } & \multicolumn{3}{|c|}{ Maximum Eigenvalue } \\
\hline & & Trace Statistic & $0.05 \mathrm{CV}$ & Prob.** & Max-Eigen Statistic & $0.05 \mathrm{CV}$ & Prob. ${ }^{* *}$ \\
\hline None & 0.664055 & $82.746^{*}$ & 63.87 & 0.0006 & $38.17825^{*}$ & 32.12 & 0.0080 \\
\hline At most 1 & 0.448239 & $44.568^{*}$ & 42.91 & 0.0338 & 20.81243 & 25.82 & 0.1999 \\
\hline At most 2 & 0.359352 & 23.755 & 25.87 & 0.0897 & 15.58464 & 19.38 & 0.1640 \\
\hline At most 3 & 0.208212 & 8.171 & 12.51 & 0.2380 & 8.171156 & 12.52 & 0.2380 \\
\hline
\end{tabular}

The long-run cointegrating equation based on Fully Modified Least Square (FMOS) for china is (t-statistics in parenthesis):

$G D P=0.16 A G R+0.56 M N F+0.30 S R V+0.39$
For Ethiopian case (Table 3) we found only cointegrating relationship among GDP, AGR, MNF and SRV at the 5\% significance level.

\section{$\left(6.83^{* * *}\right) \quad\left(21.48^{* * *}\right) \quad\left(20.35^{* * *}\right)\left(2.10^{* *}\right)$}

Table 3: Johansen Cointegration test for Ethiopia

\begin{tabular}{|c|c|c|c|c|c|c|c|}
\hline \multirow{2}{*}{ Hypothesized No. of CE(s) } & \multirow{2}{*}{ Eigenvalue } & \multicolumn{3}{|c|}{ Unrestricted Cointegration Rank Test Intercept without trend } \\
\cline { 3 - 8 } & & \multicolumn{3}{|c|}{ Trace } & \multicolumn{3}{|c|}{ Maximum Eigenvalue } \\
\cline { 3 - 8 } & & Trace Statistic & 0.05 CV & Prob. $^{* *}$ & Max-Eigen Statistic & 0.05 CV & Prob.* \\
\hline None & 0.765823 & $49.497^{*}$ & 47.86 & 0.0348 & $30.48528^{*}$ & 27.58 & 0.0206 \\
\hline At most 1 & 0.330329 & 19.012 & 29.79 & 0.4921 & 8.420340 & 21.13 & 0.8762 \\
\hline At most 2 & 0.281378 & 10.591 & 15.49 & 0.2379 & 6.938823 & 14.26 & 0.4964 \\
\hline At most 3 & 0.159666 & 3.6531 & 3.84 & 0.0560 & 3.653064 & 3.84 & 0.0560 \\
\hline
\end{tabular}

Note: Trace test and Maximum Eigenvalue indicates 1 cointegrating equations at the 0.05 level;

* denotes rejection of the hypothesis at the 0.05 level;

**MacKinnon-Haug-Michelis (1999) p-values. CV is critical value.

The long-run cointegrating equation based on Fully Modified Least Square (FMOS) for Ethiopia is ( $\mathrm{t}$-statistics in parenthesis) is:

$$
\begin{aligned}
& G D P=0.44 A G R+0.12 M N F+0.45 S R V+0.69 \\
& \left(6.83^{* * *}\right) \quad\left(21.48^{* * *}\right) \quad\left(20.35^{* * *}\right)\left(2.10^{* * *}\right)
\end{aligned}
$$

\section{Granger causality}

Granger Causality (1969) analyzed that if the variables are cointegrated then there should be at least one direction of causality between the two variables will exist. Granger Causality tests are sensitive to the lag length of the variables. Therefore, we used one year lag to assess the Granger Causality among the GDP, AGR, MNF and SRV. Table 4, below, which introduces the Granger causality test results of China and Ethiopia. The result shows that there is at least one directional causality among the variables. From Table 5, we found that the null hypothesis which is "MNF does not Granger cause AGR, SRV, and GDP", and the "AGR, SRV, GDP does not Granger cause MNF" are rejected at $0.001 \%$ significant level in China. This indicates that the manufacturing sector has a bi-directional
Granger cause with GDP, agriculture and SRVs for China. We also accept the alternative hypothesis "GDP Granger cause SRV" as well as "SRV Granger cause GDP" in China. While, for Ethiopian case, we only accept the bi-directional Granger causality among agriculture and GDP.

Table 4: Granger causality result for China and Ethiopia

\begin{tabular}{|c|c|c|c|c|}
\hline \multirow{2}{*}{ Null Hypothesis (H0) } & \multicolumn{2}{|c|}{ China $(\mathrm{N}=37)$} & \multicolumn{2}{c|}{ Ethiopia (N=23) } \\
\cline { 2 - 5 } & F-Stat. & Prob. & F-Stat. & Prob. \\
\hline GDP does not Granger Cause AGR & 5.37 & $0.026^{* *}$ & 10.51 & $0.004^{* * *}$ \\
\hline AGR does not Granger Cause GDP & 1.10 & 0.300 & 9.65 & $0.005^{* *}$ \\
\hline MNF does not Granger Cause AGR & 19.76 & $0.000^{* * *}$ & 4.51 & $0.046^{* *}$ \\
\hline AGR does not Granger Cause MNF & 6.67 & $0.014^{* *}$ & 0.16 & 0.692 \\
\hline SRV does not Granger Cause AGR & 0.53 & 0.47 & 10.10 & $0.004^{* * *}$ \\
\hline AGR does not Granger Cause SER & 0.56 & 0.45 & 2.96 & 0.101 \\
\hline MNF does not Granger Cause GDP & 34.47 & $0.000^{* * *}$ & 0.77 & 0.389 \\
\hline GDP does not Granger Cause MNF & 21.31 & $0.000^{* * *}$ & 2.57 & 0.124 \\
\hline SRV does not Granger Cause GDP & 13.44 & $0.000^{* * *}$ & 5.09 & $0.036^{* *}$ \\
\hline GDP does not Granger Cause SER & 19.97 & $0.000^{* * *}$ & 1.15 & 0.296 \\
\hline SRV does not Granger Cause MNF & 14.92 & $0.000^{* * *}$ & 4.70 & $0.043^{* *}$ \\
\hline MNF does not Granger Cause SER & 32.62 & $0.000^{* * *}$ & 0.22 & 0.642 \\
\hline $\begin{array}{l}\text { Note: **,*** are significant level at 5\% and } 1 \% \text { respectively, } \\
\text { and rejection of null hypothesis. }\end{array}$ \\
\hline
\end{tabular}




\section{Multiple regression (OLS) analysis}

As shown in Table 5 the multiple regression analysis model goodness fit of the dependent variable (GDP) is highly explained the by independent variables (AGR, MNF and SRV) in both countries with $\mathrm{R}^{2} 99.9 \%$.

\section{Model Diagnostic}

The diagnostic tests results presented in Fig. 3 showed that CUSUM and CUSUMSQ test statistics are falling inside the critical bounds of $5 \%$ significance. This implies that the estimated coefficients are liable and stable of the long-run and short-run estimates over the period of 1978-2014 and 19922014 for China and Ethiopia, respectively. Therefore, we can assume that the coefficients of the given regression are stable.
Table 5: Multiple regression (OLS) result for China and Ethiopia

\begin{tabular}{|c|c|c|c|c|c|c|c|c|}
\hline \multicolumn{9}{|c|}{ Dependent Variable: GDP } \\
\hline \multirow[t]{2}{*}{ Variable } & \multicolumn{4}{|c|}{ China } & \multicolumn{4}{|c|}{ Ethiopia } \\
\hline & Coef. & S.E & t-Stat. & Prob. & Coef. & S.E & t-Stat. & Prob. \\
\hline $\mathrm{C}$ & 0.284 & 0.126 & 2.246 & $0.0315^{* *}$ & 0.683 & 0.148 & 4.614 & $0.0002^{* * *}$ \\
\hline AGR & 0.180 & 0.015 & 11.781 & $0.0000^{* * *}$ & 0.466 & 0.015 & 31.850 & $0.0000^{* * *}$ \\
\hline MNF & 0.548 & 0.017 & 32.223 & $0.0000^{* * *}$ & 0.114 & 0.023 & 4.956 & $0.0001^{* * *}$ \\
\hline SRV & 0.307 & 0.010 & 30.211 & $0.0000^{* * *}$ & 0.440 & 0.021 & 21.071 & $0.0000^{* * *}$ \\
\hline \multicolumn{2}{|c|}{ R-squared } & \multicolumn{3}{|c|}{0.999956} & \multicolumn{4}{|c|}{0.999571} \\
\hline \multirow{2}{*}{\multicolumn{2}{|c|}{\begin{tabular}{|c|} 
Adjusted R-squared \\
Prob. (F-statistic)
\end{tabular}}} & \multirow{2}{*}{\multicolumn{3}{|c|}{$\begin{array}{l}0.999952 \\
0.000000\end{array}$}} & \multirow{2}{*}{\multicolumn{4}{|c|}{0.999503}} \\
\hline & & & & & & & & \\
\hline \multicolumn{2}{|c|}{ Heteroscedasticity } & \multicolumn{3}{|c|}{$\begin{array}{l}6.04(0.11) \text { chi-square } \\
\left(\chi^{2}\right)=3\end{array}$} & \multicolumn{4}{|c|}{$\begin{array}{l}2.99(0.39) \text { chi-square } \\
\left(\chi^{2}\right)=3\end{array}$} \\
\hline
\end{tabular}
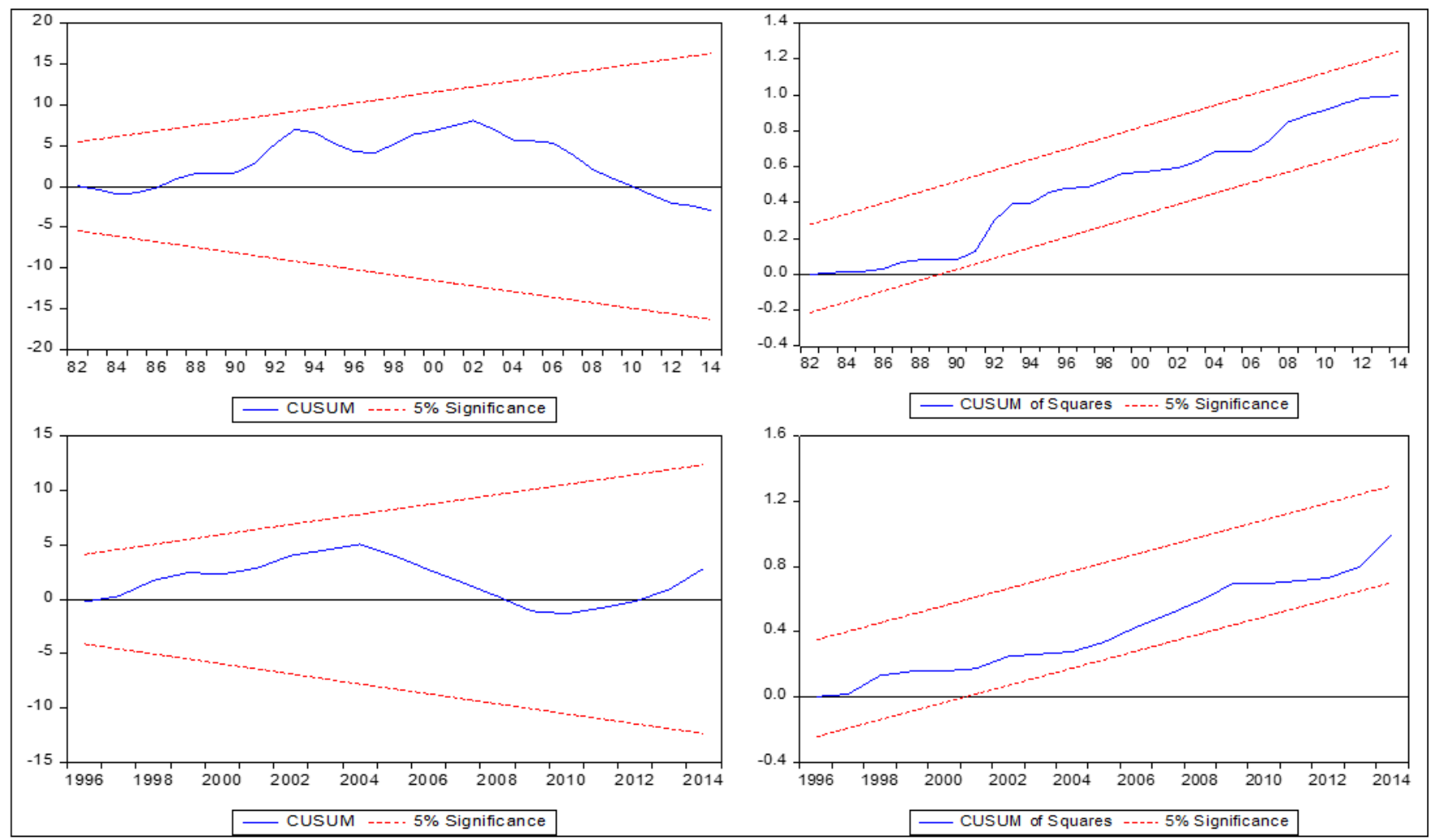

Fig. 3: CUSUM and CUSUMSQ for China and Ethiopia

\section{Discussions}

The cointegration result for China indicated that there is longrun and short-run strong relationship among economic growth and economic sectors of agriculture, manufacture, and service. Assuming that other economic sectors constant, an increase of MNF by $1 \%$, the Chinese economy will boost-up by $0.56 \%$ in long-run compared to SRV and AGRs, $0.30 \%$ and $0.16 \%$, respectively. In short-run, an increase $1 \%$ in $\mathrm{MNF}$, the Chinese economy grew by $0.55 \%$ and followed by SRV $(0.31 \%)$ and AGR $(0.18 \%)$. The result demonstrates that the MNF taking the highest share of the country economic growth in long-run and short-run. A similar result also found by Hussin and Yik, (2012), and Hussin and Ching (2013). The share of agriculture in GDP has declined significantly over time, the contribution of agricultural production has maintained an upward trend.
For Ethiopian situations, there is also long-run and shortrun cointegration relationship among economic growth and economic sectors. In Ethiopia, the service and agriculture taking the higher share in the GDP of the country than the MNF. In long-run, $1 \%$ increase in SRV the GDP mounted by $0.45 \%$. Similarly, an increase $1 \%$ AGR will boost the country economy by $0.44 \%$, in long-run. While $1 \%$ increase in the MNF can increase $0.12 \%$ economic growth in Ethiopia in long-run. In short-run, AGR takes the lion-share in Ethiopian GDP, which 1\% increase annual AGR growth will boost-up the country economy by $0.47 \%$. While service and MNFs are contributing $0.44 \%$ and $0.11 \%$, respectively. The result demonstrated that the MNF in Ethiopia contribution is under development. 
The Granger causality result showed that the MNF has strong bi-directional linkage with GDP, agriculture and service giants for China. There is also a strong inter-sectorial bidirectional linkage between SRV and GDP in China. The result revealed that GDP, AGR, and SRV can help in the future MNF and the fact MNF growth can help to predict the economy, AGR and SRV growth in China. Similarly, GDP growth can predict the SRV growth and vise-verse in China. The result is consistent with the study conducted by Wang and Li (2010) for China situation on time series data from 1990 to 2008. While for Ethiopia, GDP and AGR have the only bi-directional Granger causes variables. There is a unidirectional Granger causality from GDP to AGR in China. The SRV has unidirectional Granger cause to AGR and MNFs as well as GDP for Ethiopia. In developed countries, the empirical evidence point out that the share of AGR was fell down relative to industry and services giants, nevertheless it grew in absolute terms, while the interdependencies between economic sectors, and the potential of agriculture to stimulate industrialization (Singer, 1979; Adelman, 1984; Hwa, 1988; Vogel, 1994). Thus, our result demonstrated that in China, there is strong inter-sectoral linkage to boost up the economic growth, while in Ethiopia the inter-sectorial linkage is weak compared to China. Therefore, Ethiopia should learn some economic development policies to improve the contribution of MNF to boom the country's economic growth.

\section{CONCLUSIONS AND REMARK}

This paper examine the interdependency and linkage of economic sectors and their contribution to economic growth of respective countries. The empirical analysis confirms that there is a long-run and short-run relationship among economic sectors and with GDP in both countries. The economic sectors have a strong and positive contribution to the economic growth of both countries. The MNF holds the majority share of GDP in China while AGR taking the lion-share in the economic development of Ethiopia. This might be due to the country's economic policy, where Chinese economy transforms the subsistence agriculture and state-controlled economy to a marketoriented open-door policy which encourages the manufacturing and construction sector in the early 1980's. The Ethiopian MNF still under development while the government had put incentives to encourage the sector. According to the Granger causality result in China, the MNF has strong bi-directional linkage with GDP, AGR and SRV. There is also a strong inter-sectorial bi-directional linkage between SRV and GDP. The result revealed that there are interdependency and linkage among GDP and economic sectors. However, in Ethiopia, there is only found interdependency linkage among GDP and AGR. This indicates that the country economy highly dependent on AGR as well as the economy also support the AGR.

Therefore, from a policy perspective, Ethiopian policy makers need to formulate agro-processing industries to ensure the transformation of the agricultural sector to the manufacturing sector as well as maintain inter-sectorial linkage and sustain the country's economic growth.

\section{REFERENCES}

ADB (African Development Bank), (2015). Africa Statistical Yearbooks, http://www.afdb.org/fileadmin/uploads/afdb/Documen ts/Publications / African_Statistical_Yearbook_2014.pdf.

Blunch, N.H., \& Verner, D., (2006). Shared sectorial growth versus the dual economy model: Evidence from Cote d'Ivoire, Ghana, and Zimbabwe. Journal Compilation, African Development Bank.

Brown RL, Durbin J, Evans JM (1975). Techniques for testing the consistency of regression relations over time. Journal of the Royal Statistical Society, 37:149-92.

Chang, J.J., Chen, B.L., \& Hsu. M., (2006). Agricultural Productivity and Economic Role of Tax Revenues and Infrastructures. Southern Economic Journal, 72(4), 891-914.

Dickey, D. A., \& Fuller, W. A., (1979). Distribution of the estimators for autoregressive time series with a unit root. Journal of the American Statistical Association, 74, 427-431.

Dickey, D. A., \& Fuller, W. A., (1981). Likelihood ratio statistics for autoregressive time series with a unit root. Econometric, 49 (4), 1057-1072.

Elhiraika, A. B., (2008). Promoting manufacturing to accelerate economic growth reduce volatility in Africa. Paper prepared at the African Economic Conference, jointly organized by the African Development Bank and UNECA in Tunis, Tunisia.

Engle, R.F. Granger, C.W. (1987). Co-integration and error correction: representation, estimation, and testing. Econometrica, 251-276.

Granger, C.W., (1969). Investigating causal relations by econometric models and eross spectral methods. Econometrica, 37(3): 424-438.

Granger, C.W., (1988). Some Recent Developments in a Concept of Causality. Journal of Econometrics 39, 199-211.

Gujarati, D. N., (2011). Basic Econometrics, Eighth reprint, McGraw-Hill Publications, New York.

Hussin F. \& Ching C. W., (2013). The Contribution of Economic Sectors to Economic Growth: The Cases of Malaysia and China. International Journal of Academic Research in Economics and Management Sciences, 2013, Vol. 2, No. 2, 36-48.

Hussin, F. \& Yik, S. Y., (2012). The Contribution of Economic Sectors to Economic Growth: The Cases of China and India, Research in Applied Economics, 4(4), 38-53.

Johansen, S. (1988). Statistical analysis of cointegration vectors. Journal of economic dynamics and control, 12(2), 231-254.

Johansen, S. and Juselius, K., (1990). Maximum Likelihood Estimation and Inference on Cointegration - With Applications to the Demand for Money. Oxford Bulletin of Economics and Statistics, 52, 169-210.

Katircioglu, S. T., (2006). Causality between agriculture and economic growth in a small nation under political isolation: A case from North Cyprus. International Journal of Social Economics. Vol. 33(4), 331-343.

Libanio, G., (2006). Manufacturing industry and economic growth in Latin America: A Kaldorian approach. CEDEPLAR, Brazil: Federal University of Minas Gerais.

Lin, J. \& Koo W. W., (1990). Economic Development in the Agricultural and Industrial Sectors in the People's Republic of China. Ag. Econ. Rpt. No. 263, Dept. of Ag. Econ., North Dakota State University, Fargo. 
Linden, M., \& Mahmood T., (2007). Long run relationships between sector shares and economic growth - A Panel Data Analysis of the Schengen Region. Keskustelualoitteita, 50, 1-36.

Mirza M. \& Uddin M., (2015). Causal Relationship between Agriculture, Industry and Services Sector for GDP Growth in Bangladesh: An Econometric Investigation. Journal of Poverty, Investment and Development Vol.8, 2015, 124-129.

National Bank of Ethiopia (NBE), (2014). The Overall Economic Performance. Annual Report. Addis Ababa, Ethiopia.

Subramaniam, V. and Reed, M., (2009). Agricultural intersectorial linkages and its contribution to economic growth in the transition countries, Contributed Paper Prepared for Presentation at the International Association of Agricultural Economists Conference, Beijing, China.

Wang, S., \& Li, D., (2010). An empirical analysis on the relationship between service industry and economic growth. Proceedings of 2010 International Conference on Industry Engineering and Management.

Wang, X. Z., Wu, S. L., \& Gao F., (2010). The relationship between economic growth and agricultural growth: The case of China. Paper presented at International Conference on E-Business and E-Government (ICEE), Guanghou, China.

\section{SOCIAL SCIENCE RESEARCH NETWORK \\ 2171 Monroe Avenue, Suite 203, Rochester, NY 14618, USA http://www.ssrn.com/en/ \\ AJTP Link: http://www.ssrn.com/link/American-Journal-Trade-Policy.html}

